\title{
Vertical difference of soil CO2 flux and its driving factors in Loess Hilly Region, China
}

\author{
Wanglin $\mathrm{Hao}^{1}$, Bin $\mathrm{Xia}^{1}$, Binbin $\mathrm{Li}^{2}$, and Ming-xiang $\mathrm{Xu}^{3}$ \\ ${ }^{1}$ Institute of Soil and Water Conservation Chinese Academy of Sciences and Ministry of \\ Water Resources \\ ${ }^{2}$ Chinese Academy of Sciences \\ ${ }^{3}$ State Key Laboratory of Soil Erosion and Dry land Farming
}

November 10, 2020

\begin{abstract}
The diffusion of carbon mineralization in vertical profiles is an important process of $\mathrm{CO} 2$ emission. However, due to the relatively slow and lagging change of subsoil environment compared with the surface soil, the process of carbon mineralization and diffusion is often ignored, and the process and mechanism of deep carbon transfer to the soil-atmosphere interface are still unclear. we studied the vertical difference of $\mathrm{CO} 2$ flux and its driving mechanism in Robinia pseudoacacia plantation of different stand ages. The results show that: (1) in the $0-200 \mathrm{~cm}$ layer, the CO2 flux shows a double peak seasonal trend. Among them, the total CO2 flux of Robinia pseudoacacia forest in 10 years was larger. (2) Dynamic evaluation can reduce the uncertainty of static evaluation, and the contribution of deep CO2 flux to the soil atmosphere interface is stable, between 21.81-24.42\%; (3)Temperature sensitivity of CO2 flux (expressed as Q10) significantly increases with soil depth, and the response of water to $\mathrm{CO} 2$ flux is different at different section. There is a significant correlation between the deep $\mathrm{CO} 2$ flux and soil organic carbon (SOC), but there is a reverse feedback effect in the shallow profile. (4) T \& M \& C model is more conducive to the accurate prediction of deep CO2 flux. All in all, this study is of great significance to the study of the stability of deep soil carbon, the dynamic change of soil carbon pool and the mechanism of deep carbon diffusion to the surface in the loess hilly area.
\end{abstract}

Title:Vertical difference of soil $\mathrm{CO}_{2}$ flux and its driving factors in Loess Hilly Region, China Wanglin $\mathrm{Hao}^{\mathrm{a}, \mathrm{b}, \mathrm{c}}$, Bin Xia ${ }^{\mathrm{a}, \mathrm{b}}$, Binbin Li ${ }^{\text {a, b}}$, Mingxiang Xu ${ }^{\mathrm{a}}$, b, d,*

${ }^{a}$ State Key Laboratory of Soil Erosion and Dryland Farming on the Loess Plateau, Institute of Soil and Water Conservation, Chinese Academy of Sciences and Ministry of Water Resources, 712100, Yangling, shaanxi,China.

b University of Chinese Academy of Sciences, 100190, Beijing ,China.

c Department of Life Sciences ,LuLiang University, 033000, Lvliang,China.

d Institute of Soil and Water Conservation, Northwest A\&F University, 712100, Yangling, shaanxi,China.

Correspondence

Mingxiang $\mathrm{Xu}^{\mathrm{a}, \mathrm{b}, \mathrm{d}}$

a State Key Laboratory of Soil Erosion and Dryland Farming on the Loess Plateau, Institute of Soil and Water Conservation, Chinese Academy of Sciences and Ministry of Water Resources, 712100, Yangling, Shaanxi ,China

b University of Chinese Academy of Sciences, 100190, Beijing ,China. 
d Institute of Soil and Water Conservation, Northwest A\&F University, 712100, Yangling, shaanxi,China,

E-mail of corresponding author: xumx@nwsuaf.edu.cn

Address: 26 Xinong Road Yangling, Shaanxi 712100, China

\section{A B S T R A C T}

The diffusion of carbon mineralization in vertical profiles is an important process of $\mathrm{CO}_{2}$ emission. However, due to the relatively slow and lagging change of subsoil environment compared with the surface soil, the process of carbon mineralization and diffusion is often ignored, and the process and mechanism of deep carbon transfer to the soil-atmosphere interface are still unclear. we studied the vertical difference of $\mathrm{CO}_{2}$ flux and its driving mechanism inRobinia pseudoacacia plantation of different stand ages. The results show that: (1) in the $0-200 \mathrm{~cm}$ layer, the $\mathrm{CO}_{2}$ flux shows a double peak seasonal trend. Among them, the total $\mathrm{CO}_{2}$ flux of Robinia pseudoacacia forest in 10 years was larger. (2) Dynamic evaluation can reduce the uncertainty of static evaluation, and the contribution of deep $\mathrm{CO}_{2}$ flux to the soil atmosphere interface is stable, between 21.81-24.42\%; (3)Temperature sensitivity of $\mathrm{CO}_{2}$ flux (expressed as $\mathrm{Q}_{10}$ ) significantly increases with soil depth, and the response of water to $\mathrm{CO}_{2}$ flux is different at different section. There is a significant correlation between the deep $\mathrm{CO}_{2}$ flux and soil organic carbon (SOC), but there is a reverse feedback effect in the shallow profile. (4) $\mathrm{T} \& \mathrm{M} \& \mathrm{C}$ model is more conducive to the accurate prediction of deep $\mathrm{CO}_{2}$ flux. All in all, this study is of great significance to the study of the stability of deep soil carbon, the dynamic change of soil carbon pool and the mechanism of deep carbon diffusion to the surface in the loess hilly area.

Keywords: $\mathrm{CO}_{2}$ flux;Temperature;Moisture;SOC;Deep layer

\section{Highlights:}

(1) At the layers of $0-200 \mathrm{~cm}$, the $\mathrm{CO}_{2}$ flux exhibits a certain double-peak seasonal and vertical decrease change trend.

(2) The contribute of $\mathrm{CO}_{2}$ flux at deep layers $(80-200 \mathrm{~cm})$ to the soil-atmosphere interface is stable, lying between $21.81-24.42 \%$.

(3) Temperature sensitivity of $\mathrm{CO}_{2}$ flux (expressed as $\mathrm{Q}_{10}$ ) significantly increases with soil depth.

(4) Temperature, moisture, and soil organic carbon cooperatively contribute to soil $\mathrm{CO}_{2}$ flux, and the $\mathrm{T} \&$ $\mathrm{M} \& \mathrm{C}$ model is more conducive to accurate prediction of $\mathrm{CO}_{2}$ flux at deep layers.

\section{Introduction}

Climate system and the global carbon cycle have formed a positive feedback loop to reinforce each other(Friedlingstein, Dufresne, Cox, \& Rayner, 2003). Carbon as an important influence factor of the greenhouse effect has become a research hotspot in the scientific community. About 1,500 Gt of carbon is stored in the soil in the form of organic matter, which is 2 to 3 times as much as the carbon pool of terrestrial vegetation or global atmospheric carbon pool. Subtle changes in soil organic carbon pool may cause large fluctuations in atmospheric $\mathrm{CO}_{2}$ concentration, which in turn will affect the greenhouse effect and global climate change (Davidson, Trumbore, \& Amundson, 2000). Therefore, study of the stabilization mechanism of organic carbon and its controlling factors is essential for a correct understanding of the biosphere carbon cycle, the importance of soil organic carbon to ecosystem processes and the feedback to climate change(Jobbagy \& Jackson, 2000).

Changes of land use and vegetation cover pattern have key influence on the carbon cycle of terrestrial ecosystems (Willcock et al., 2016), All of them affect greenhouse gas production and emission by altering the soil microenvironmen, soil physicochemical processes and microbial activities(Ball, McTaggart, \& Watson, 2002) (Flechard et al., 2007). Due to the character of fast growing,drought resistance, thinness resistance and hardwood propertie, Black locust has become an important tree for afforestation and plays an important role in the carbon cycle of ecosystem on the hilly losee platea of china. The stabilization mechanism of soil 
organic carbon in Robinia pseudoacaciaplantation on the Loess Plateau is of great significance for further understanding of regional climate changes caused by pattern changes in the organic carbon under conversion of cropland to forest.

The stability of organic carbon in the soil depends on soil properties, environmental factors and influence of human activities. Most of the current understanding of the process of soil carbon storage and release comes from the study of the main surface soil (Richter \& Mobley, 2009; Zabowski, Whitney, Gurung, \& Hatten, 2011). However, deep soil serves as a huge organic carbon pool in terrestrial ecosystems, its carbon storage is three times as much as that of surface soil (Fontaine, Barot et al. 2007). A little change in the organic carbon (SOC) cycle of deep soils may cause the release of large amounts of $\mathrm{CO}_{2}$ and have a significant impact on the global carbon cycle (X. Wang et al., 2014).

Although the vertical distribution of soil organic carbon decreasing with the increase of soil profile depth has already been recognized, people pay less attention to the dynamics of deep soil carbon due to the low content of deep soil organic carbon (Davidson \& Ackerman, 1993; Post \& Kwon, 2000). Most studies focus on spatial and temporal variation in organic carbon mineralization and soil $\mathrm{CO}_{2}$ flux at soil surface layer (ArchMiller, Samuelson, \& Li, 2016; Mande, Abdullah, Aris, \& Ainuddin, 2015; Pang, Bao, Zhu, \& Cheng, 2013), reports on $\mathrm{CO}_{2}$ flux in deep soil layers are very rare (Jassal R, 2005; Liang N S, 2003; Wiaux F, 2015). In addition, since the $\mathrm{CO}_{2}$ flux at the soil-atmosphere interface is a superposition of $\mathrm{CO}_{2}$ emissions caused by organic carbon mineralization from different depths of soil layers. For lack of comprehensive understanding of contribution of soil resources at different depths to SOC mineralization, it will produce larger errors to predict the overall soil carbon pool variation characteristics based on soil surface layers (Takahashi, Hiyama, Takahashi, \& Fukushima, 2004). Therefore, distinguishing the characteristics of SOC mineralization variation at different depths, especially in deep layers, will help to improve the accuracy of the soil carbon emission prediction model and further understand the carbon emission mechanism (Subke, Reichstein, \& Tenhunen, 2003; Takahashi et al., 2004).

In summary, understanding the stability of soil organic carbon is the key to the study of soil carbon sequestration in plantation forests. How does the process of soil organic carbon mineralization change with soil depth in the Robinia pseudoacacia plantation ecosystem on the Loess Plateau? Which characteristics of carbon fluxes changes in different sections of deep layers and which factors affecte them? All of these issues need to be further studied. In this study, we monitored the $\mathrm{CO}_{2}$ concentration and soil physico-chemical environment at different soil profiles in the artificial Robinia pseudoacaciaof different stand ages and crop land on the hilly losee platea. The aims of this research were: (1) to determine distribution of soil $\mathrm{CO}_{2}$ flux at different profiles based on Fick's first law; (2) to understand the response of soil $\mathrm{CO}_{2}$ flux to soil temperature ,moisture and soil organic carbon(SOC) at different profiles; (3) to define the contribution of $\mathrm{CO}_{2}$ flux in deep layers to soil-atmosphere interface; (4) to explore multi-factor coordination and construct prediction model. The results of this study contribute to clarify the production process of soil $\mathrm{CO}_{2}$ in deep layers and the response mechanism of $\mathrm{CO}_{2}$ flux at different profils for scientifically assessing soil carbon emission effects of vegetation restoration, and to provide a theoretical basis for further clarifying the stability of soil carbon and the dynamic change of soil carbon pool in Robinia pseudoacacia on the hilly losee platea.

\section{Methods}

\subsection{Experimental site and climatic conditions}

Our study was conducted at Zhifanggou watershed of Ansai County (109¹4'36" - 109deg16'03"E, 36deg42'42" - 36deg46'28"N), in the central area of the Loess Hilly Region, in the Shaanxi Province, China, where the terrain was broken and the gully was vertical and horizontal. The experimental site was located in the Semi-arid monsoon climate zone at about $1200 \mathrm{~m}$ above sea level and had a slope of 25-35\%. Average annual air temperature at the watershed is 8.8 with annual evaporation $1463 \mathrm{~mm}$ and total annual precipitation $549.1 \mathrm{~mm}$, about $61.1 \%$ of which occurs from July to September. The region has an area of $8.27 \mathrm{~km}^{2}$ with thick soil layer, where the soil is mainly composed of loess soil developed on the loess parent material. Due to serious soil erosion, since the 1970s, large-scale ecological restoration projects based on 
vegetation restoration have been gradually implemented, and it has an important impact on soil carbon flux in the area. The common types of vegetation restoration in this area are: artificial forests dominated by black locust (Robinia pseudoacacia ); artificial shrubs dominated by caragana (Caragana korshinskii) and sea buckthorn (Hippophae rhamnoides), natural shrubs, and abandoned steppe.

\subsection{Plots and treatments}

We selected the typical Robinia pseudoacacia as the research object in the loess hilly region, which was the key area for the restoration and reconstruction of ecological environment. In mid-September, 2012, Robinia pseudoacacia with four kinds of stand age (CH10a, CH20a, CH30a, CH40a) and the same soil type (Loessal Soil) were selected in the Zhifanggou watershed. At the same time, slope crop land was selected as the control for explaining the effect of soil different environment on soil carbon flux. The vegetation and topographical features of different plot are shown in Table 1.

\subsection{Soil carbon dioxide sampling and measurement}

The carbon dioxide concentration was measured with a classical gas well method (Fig. 1). We selected 3 representative points for sampling in 5 plots, drilled holes with soil drills corer at a distance of 200, 140, and $80,20,5 \mathrm{~cm}$ underground. After that, we buried alternately gas collectors, which were inserted one end of a rigid plastic tube with an inner diameter of $4 \mathrm{~mm}$. the joint was sealed with silicone, the other end was led to the ground with the rubber hose inserted and a rubber stopper sealed. Finally, the soil was backfilled uniformly. The sampling was started after the backfilled soils tend to coincide with the surrounding soil. Soil $\mathrm{CO}_{2}$ samples were collected at the middle ten days of each month from September 2012 to September $2013,5 \mathrm{~mL}$ of gas was taken from each collector, and the concentration of carbon dioxide was determined by gas chromatography. Before each measurement, pure $\mathrm{CO}_{2}$ gas was used as the standard curve.

\subsection{Soil temperature and moisture measurement}

The temperature and moisture of soil were measured using a soil temperature and moisture measuring probe (Em 50, Decagon Inc, USA) (Fig.1). At the same time as the $\mathrm{CO}_{2}$ gas collector was installed, the probe was placed a distance of 200,140,80,20,5 cm underground and surface at the same time with the $\mathrm{CO}_{2}$ gas collectors .

\subsection{Soil organic carbon measurement}

Soil at the depth of $0^{\sim} 5 \mathrm{~cm}, 5 \sim 20 \mathrm{~cm}, 20^{\sim} 80 \mathrm{~cm}, 80^{\sim} 140 \mathrm{~cm}, 140^{\sim} 200 \mathrm{~cm}$ was sampled using a $5 \mathrm{~cm}$ diameter soil corer with 3 subsamples in each plot, mixed, air-dried, grinded and sieved for soil organic carbon (SOC) measurement. The SOC was measured by the potassium dichromate external heating method (Springer \& Klee, 2010).

\subsection{The calculation of $\mathrm{CO}_{2}$ flux in deep soil layers}

The $\mathrm{CO}_{2}$ flux (Fs, $\mu \mathrm{mol} \mathrm{m} \mathrm{m}^{-2} \mathrm{~s}^{-1}$ ) in deep soil layers is simulated using Fick's First Law of Diffusion.

$\mathrm{Fs}=-\mathrm{Ds}_{\Delta} \mathrm{C}(\mathrm{z}) /{ }_{\Delta} \mathrm{z}(1)$

Where, Ds is the diffusion coefficient $\left(\mathrm{m}^{2} \mathrm{~s}^{-}\right)$of $\mathrm{CO}_{2}$ in the soil, $\mathrm{C}$ is the $\mathrm{CO}_{2}$ concentration $\left(\mu \mathrm{mol} \mathrm{m}{ }^{-3}\right)$, and $\mathrm{z}$ is the depth of the soil layer $(\mathrm{m})$.

$\mathrm{Ds}=\varepsilon \mathrm{Da}(2)$

Where, $\mathrm{Da}$ is the diffusivity of $\mathrm{CO}_{2}$ in the free atmosphere, $\mathrm{Da}=1.47 \times 10^{-5} \mathrm{~m}^{2} \mathrm{~s}^{-1}$; $\varepsilon$ is the relative diffusivity of $\mathrm{CO}_{2}$ in the soil.

$\varepsilon$ is simulated commonly using empirical models as follows:

Moldrup-2000 model: $\varepsilon=(\varphi-\text { th })^{2.5} \varphi^{-1}(3)$ 
Where, $\vartheta$ is the soil volumetric water content $\left(\mathrm{cm}^{3} \mathrm{~cm}^{-3}\right) ; \varphi$ is the soil porosity, $\varphi=\rho_{b} / \rho_{m}, \rho_{b}$ is the soil volume mass $\left(\mathrm{g} \mathrm{cm}^{-3}\right), \rho_{\mathrm{m}}$ is the soil specific gravity, and $\rho_{\mathrm{m}}=\left(2.65 \mathrm{~g} \mathrm{~cm}^{-3}\right)$ in the mineral soil, $\mathrm{m}$ is a constant, $\mathrm{m}=3$ in this study.

According to the basic characteristics of topsoil $\mathrm{CO}_{2} \mathrm{flux}$, the proper calculation model was chose for correcting the flux calculation.

\subsection{Statistical analyses}

Correlation analysis and analysis of variance were performed using SAS V8.0 statistical software (SAS Institute Inc., Cary, NC, USA). Graphing analysis was carried out with Origin 2018 software (Origin Lab, USA). Double-way ANOVA was used to analyze the effects of stand age and soil depth on soil $\mathrm{CO}_{2}$ flux, considered treatment (stand age and soil depth) as the fixed effect, replication as the random effect, and time of measurement as the repeated measure variable. Means were separated by using the least significance difference test. Correlation analysis was done to determine the relationships between soil $\mathrm{CO}_{2} f l u x, \mathrm{SOC}$, temperature, and moisture when treatments and interactions were significant. Statistical significance was evaluated at $\mathrm{P}=0.05$, unless otherwise stated.

\section{Results}

\subsection{Soil carbon dioxide flux}

Two-way analysis of variance showed that there was no significant difference in soil $\mathrm{CO}_{2}$ fluxes of land-use types, but significant difference at profiles $(\mathrm{P}<0.01)$, and there were some interaction effects between land-use types and profiles $(\mathrm{P}<0.01)$ (Table 2$)$. At the soil profile of $0-200 \mathrm{~cm}$, with the depth increases, the annual average soil $\mathrm{CO}_{2}$ flux in crop land (CK) and Robinia pseudoacacia of different stand ages (experimental group) showed the downtrend. The soil $\mathrm{CO}_{2}$ flux in shallow layers $(0-20 \mathrm{~cm})$ of Robinia pseudoacaciadecreased significantly with the increase of soil depth, the range of change was $0.12-3.91 \mu \mathrm{mol} \mathrm{m}^{-2} \mathrm{~s}^{-1}$; while the soil $\mathrm{CO}_{2}$ flux of the deep layers $(80-200 \mathrm{~cm})$ only changed slightly from 0.02 to $0.50 \mu \mathrm{mol} \mathrm{m}^{-2} \mathrm{~s}^{-1}$ (Fig. $2 \mathrm{~A}$ ). From sep.2012 to sep.2013, there was a two peaks trend in the soil $\mathrm{CO}_{2}$ flux. From the diagram, greater changes have taken place in shallow layers $(5-20 \mathrm{~cm})$ than that in deep layers, and the peak value always appeared in Dec.2012 and Jun.2013, while the peak value in Robinia pseudoacacia of CH10a appeared in Aug.2013 (Fig. $2 \mathrm{~A})$.

\subsection{Contribution of soil $\mathrm{CO}_{2}$ flux in deep profile to soil-atmosphere interface}

In the growing season, the average proportion of $\mathrm{CO}_{2} \mathrm{flux}$ at deep layers $(80-200 \mathrm{~cm})$ to the total $\mathrm{CO}_{2}$ flux at the soil-atmosphere interface in Robinia pseudoacacia (CH10a, CH20a, CH30a, CH40a) and crop land was $11.14 \%, 21.71 \%, 27.43 \%, 23.42 \%$ and $24.00 \%$, respectively. while that was $8.50 \%, 13.17 \%, 23.83 \%, 12.67 \%$ and $19.33 \%$ in non-growing seasons. The proportion in the growing season was discrete, but the proportion in non-growth season is relatively concentrated. This indicated that the proportion of $\mathrm{CO}_{2}$ flux at deep layers fluctuated greatly ( Fig. 3A).

It is a dynamic process for the $\mathrm{CO}_{2}$ emission from each section of the profils to the soil-atmosphere interface. Therefore,the static assessment method which take the average proportion of $\mathrm{CO}_{2}$ fluxes at deep layers as index system may overestimate or underestimate contribution of $\mathrm{CO}_{2}$ flux in deep layers to soil-atmosphere interface. In order to accurately assessment contribution of $\mathrm{CO}_{2}$ flux in deep layers to soil-atmosphere interface, we took accumulated variance contribution of proportions as index system dynamic assessment. During the whole season,accumulated variance contribution of proportions at the deep layer $(80-200 \mathrm{~cm})$ in Robinia pseudoacacia (CH10a, CH20a, CH30a, CH40a) and crop land was 9.74\%, 23.61\%, 21.81 \%, 22.92\% and $24.42 \%$,respectively (Fig. 3B). The contribution of $\mathrm{CO}_{2}$ flux at deep layers to the total $\mathrm{CO}_{2}$ flux at soil-atmosphere interface increased with with the increase of restoration time.

\subsection{Relationships between soil $\mathrm{CO}_{2}$ flux, temperature, moisture and SOC}

The soil temperature was not significantly different in land-use types and profiles (Table 2). From Sep.2012 to Sep.2013, soil temperature reduced and then climbed up. where the change range of the temperature in 
shallow layers $(5-20 \mathrm{~cm})$ was larger than it in deep layers $(80-200 \mathrm{~cm})$, but this fluctuation of the deep layers presents an obvious hysteretic nature compared with shallow layers (Fig.2B). We used the exponential model to fit the relationship between soil $\mathrm{CO}_{2}$ flux $(\mathrm{F})$ and soil temperature $(\mathrm{T})$, and calculate the temperature sensitivity coefficient $\left(\mathrm{Q}_{10}\right)$, significant correlation was found between $\mathrm{CO}_{2}$ flux and temperature $(\mathrm{P}<0.01)$ (Fig.5). Sensitivity of soil $\mathrm{CO}_{2}$ flux to temperature in deep layers was generally higher than that in shallow layers.

Soil moisture was significantly different in land-use types and profiles $(\mathrm{P}<0.01)$, and and interaction effect existed between them (Table 2). The change trend of moisture in crop land was more complicated. On the contrary, certain difference appeared in moisture among Robinia pseudoacacia of stand ages. The moisture of shallow soil layers $(5-20 \mathrm{~cm})$ decreased and then increased with the seasons, while a slow increase trend took place in deep soil layers $(80-200 \mathrm{~cm})$. There was a quadratic function relation between soil $\mathrm{CO}_{2}$ flux $(\mathrm{F})$ and soil moisture (M) (Fig.6). On the basis of the coefficient of determination $\left(\mathrm{R}^{2}\right)$, correlation between soil $\mathrm{CO}_{2}$ flux and soil moisture in shallow layer $(5-20 \mathrm{~cm})$ was stronger than that in deep layer $(80-200 \mathrm{~cm})$.

The soil organic carbon was significantly different in different soil profile depths $(\mathrm{P}<0.01)$. The organic carbon content in the deep layers $(80-200 \mathrm{~cm})$ was significantly lower than that in the shallow layer $(5-20$ $\mathrm{cm}$ ). As the main substrate in the process of soil carbon emission, soil organic carbon (SOC) has an important impact on soil $\mathrm{CO}_{2}$ flux. Correlation analysis was carried out between soil $\mathrm{CO}_{2}$ flux and concentration of soil organic carbon in different land-use types and profiles (Table 3). The results showed that correlation at depth of $20 \mathrm{~cm}$ and $140 \mathrm{~cm}$ were significant $(\mathrm{P}<0.05)$, and it was extremely significant at depth of $200 \mathrm{~cm}(\mathrm{P}<0.01)$, but there was no significant correlation at depth of $5 \mathrm{~cm}$ and $10 \mathrm{~cm}$.

\subsection{Synergistic characteristics of impact factors and prediction models}

In order to accurately explore the effects of temperature, moisture, SOC on soil $\mathrm{CO}_{2}$ flux, multivariate correlation analysis was carried out among the three factors and soil $\mathrm{CO}_{2}$ flux at deep and shallow layers. The results showed that there were significant correlations between soil temperature, moisture, concentration of soil organic carbon and soil $\mathrm{CO}_{2}$ flux in the shallow layers $(5-20 \mathrm{~cm})(\mathrm{P}<0.01)$. Moreover, there was a significant correlation between soil moisture and temperature. $(\mathrm{P}<0.01)$ (Fig7. Heat map: A). In deep layers $(80-200 \mathrm{~cm})$, soil temperature, moisture, concentration of soil organic carbon and soil $\mathrm{CO}_{2}$ flux were significantly correlated $(\mathrm{P}<0.01)$, and there was a significant correlation between temperature, moisture and concentration of soil organic carbon $(\mathrm{P}<0.01)$ (Fig7. Heat map: B). For generality, whether in deep or shallow layers, soil temperature, moisture, and SOC had a synergistic effect on responses to soil $\mathrm{CO}_{2}$ flux.

Because soil temperature, moisture, and concentration of soil organic carbon cooperatively contributed to on soil $\mathrm{CO}_{2}$ flux, and there was a certain interaction between these influencing factors (Fig.7). The $\mathrm{CO}_{2}$ flux under different temperature, moisture and SOC distributed relatively concentrated in deep layers, and the distribution of $\mathrm{CO}_{2}$ flux in shallow layers was discrete (Fig.8). If only a single-factor model or hydrothermal two-factor model was used to predict soil $\mathrm{CO}_{2}$ flux, it is inevitable that the influence of other factors will be ignored, and the change law of soil $\mathrm{CO}_{2}$ flux would not be well described. Therefore, on the basis of previous research in the hydrothermal two-factor models (Exponential-Power model, Q 10 -hyperbolic model )(Table 4), we adopted piecewise fitting method to build up a mathematic model for soil temperature, moisture, concentration of soil organic carbon and soil $\mathrm{CO}_{2}$ flux at different layer (Table 5).

In general, value of $\mathrm{R}^{2}$ in T\&M\&C model was further improved compared to the T\&M model, and the fitting results of these models were significant (Table 4, Table 5). In order to further analyze the prediction accuracy of the model and the possibility of model generalization, we integrated some literatures which study on the vertical $\mathrm{CO}_{2}$ flux, especially the deep $\mathrm{CO}_{2}$ flux and its influencing factors, to obtain the required data including $\mathrm{CO}_{2}$ flux, temperature, moisture and $\mathrm{SOC}$ of each profile for analysis (Appendix A ). Based on T\&M\&C model and T\&M model, we used the obtained temperature, moisture, and organic carbon data to simulate the predicted $\mathrm{CO}_{2}$ flux and compare it with the measured $\mathrm{CO}_{2}$ flux, the simulated $\mathrm{CO}_{2}$ flux and measured $\mathrm{CO}_{2}$ flux fit well with the linear relationship in various types of plots (Fig.9, Fig.10). The prediction accuracy was evaluated by three variables of different dimensions $\left(\mathrm{R}^{2}\right.$, RMSE, 
MAE). Compared with the T\&M model, the $\mathrm{R}^{2}$ value of T\&M\&C model increased, but RMSE and MAE differently decreased(Appendix B ). The prediction accuracy of T\&M\&C model had an increase of about $20 \%-25 \%$, and prediction accuracy of $\mathrm{CO}_{2}$ flux steadily improved in deep layers rather than shallow layers (Fig. 11).

\section{Discussion}

\subsection{Seasonal and vertical variations of soil $\mathrm{CO}_{2}$ flux}

Because of the temporal and spatial heterogeneity in plant and animal species, activities and organic carbon matrix, soil $\mathrm{CO}_{2}$ fluxes exist strong distribution pattern of vertical heterogeneity and seasonal variation. The $\mathrm{CO}_{2}$ flux in soil vertical profile reflects the production and transport of $\mathrm{CO}_{2}$ in the soil and also provides information on the dynamics of soil $\mathrm{CO}_{2}$ (Fontaine et al., 2007; Franzluebbers et al., 2001). The soil profile of this study extends from the surface to the depth of $200 \mathrm{~cm}$. With the deepening of the soil depth, the soil $\mathrm{CO}_{2}$ flux of crop land and Robinia pseudoacacia of different stand ages is decreasing, and the $\mathrm{CO}_{2}$ flux in Robinia pseudoacacia $(80-200 \mathrm{~cm}$ ) at deep layers only changed slightly (Fig. 2A), which was affected by the interaction of land-use types and profiles $(\mathrm{P}<0.01)$ (Table 2). However, the $\mathrm{CO}_{2}$ flux at shallow layers $(5-80 \mathrm{~cm})$ has a large change, and the trend is similar to that in previous studies (Davidson, Savage, et al., 2006; Fang C M, 2005; Pumpanen et al., 2008). The difference of $\mathrm{CO}_{2}$ flux at different depth is mainly attributed to the relatively stable soil environment, lower content of soil organic carbon (Fig. 3), and small changes in soil temperature and moisture (Fig2B, Fig2C) at deep layers than shallow layers.

Due to the difference in temperature and moisture caused by seasonal changes, the characteristics of the $\mathrm{CO}_{2}$ soil flux at different profiles also presents certain easonal. Pumpanen (Pumpanen et al., 2008) and Hashimoto (Hashimoto et al., 2007) found that soil $\mathrm{CO}_{2}$ fluxes at different depths represented significant seasonal, high in summer ,low in winter, and soil $\mathrm{CO}_{2}$ fluxes are relatively high in shallow layers than deep layers. However, Risk et al (Risk, Kellman, \& Beltrami, 2002) found the opposite result, the $\mathrm{CO}_{2}$ flux in deep layers show stronger seasonality than it in shallow layers, which may be caused by land-use types and vegetation patterns in the experimental sites. In our study, there was a two peaks trend in the soil $\mathrm{CO}_{2}$ flux. The trend in shallow layers was more obvious than that in deep layer, and the peak value always appeared in Dec.2012 and Jun.-Aug.,2013 (Fig. 2A). The occurrence of double peaks indicates that the seasonal variation of $\mathrm{CO}_{2}$ flux could not be explained simply by changes of temperature and moisture. The double peaks appeared in the growing season and non-growing season, respectively. All of which can further indicate that restrictive factors affecting soil $\mathrm{CO}_{2}$ flux by vegetation root activity may be converted, and further studies on root and microbial activity are needed to explain double-peaks changes. The slight change range of $\mathrm{CO}_{2}$ flux at deep layers may be attributed to the relatively stable temperature, moisture, and the lower content of soil organic carbon.

\subsection{Contribution of $\mathrm{CO}_{2}$ flux in deep layers to soil-atmosphere interface}

The contribution of soil $\mathrm{CO}_{2}$ flux at different layers to the total $\mathrm{CO}_{2}$ flux at the soil-atmosphere interface exist some differences. The contribution is always evaluated with average proportion of soil $\mathrm{CO}_{2}$ flux at certain layer to soil-atmosphere interface. Nevertheless, with temporal and spatial change, the factors affecting the $\mathrm{CO}_{2}$ flux change, and there are dynamic changes in $\mathrm{CO}_{2}$ flux of each layers. In this study, variance contribution of proportions was introduced for dynamic evaluation,and this method can further reveal the dynamic process in the contribution of $\mathrm{CO}_{2}$ flux at profiles.

Davidson et al. (Davidson \& Trumbore, 1995) took study in forests and cultivated land of Amazon and found that soil $\mathrm{CO}_{2}$ emissions at depth of $1 \mathrm{~m}$ accounted for $70 \%-80 \%$ of total soil emissions at soil-atmosphere interface; Gaudinski' studies showed that Soil $\mathrm{CO}_{2}$ fluxes within shallow layers of $15 \mathrm{~cm}$ accounted for $63 \%$ of total soil respiration in temperate forests(Gaudinski, Trumbore, Davidson, \& Zheng, 2000); Davidson et al. (Davidson E A, 2006) found that the contribution of $\mathrm{CO}_{2}$ flux at in the O-horizon soils to total soil respiration was about $40 \%-48 \%$ in the broadleaved mixed forest of Massachusetts. Compared with the previous research results, our study focuses on the contribution of soil $\mathrm{CO}_{2}$ flux at deep layers $(<80 \mathrm{~cm})$ to the total $\mathrm{CO}_{2}$ flux. The static evaluation results show that The contribution rate of $\mathrm{CO}_{2}$ flux in Robinia 
pseudoacacia of stand ages (CH10a, CH20a, CH30a, CH40a) at deep layers to soil-atmosphere interface is generally larger in growing seasons, and the difference among different stand ages is not obvious. The soil $\mathrm{CO}_{2}$ flux of at deep layers accounts for $17.76 \%-21.86 \%$ of the total $\mathrm{CO}_{2}$ flux at soil-atmosphere interface. To sum up, that phenomenon may be due to the rich soil organic carbon content at deep layers, combined with the results of soil microbes and roots. Therefore, in the study of carbon emissions at soil-atmosphere interface,we cannot follow the traditional understanding and ignore the impact of $\mathrm{CO}_{2}$ flux deep layers just owning to its low content. According to the results of dynamic evaluation,the variation of contribution in growing season was lager than that in non-growing season, and the contribution rate in Robinia pseudoacacia of CH10a was $27.46 \%$ in the growing season, which was larger than that in other stand ages, showing a certain heterogeneity. Similar results have been reported that, Pumpanen (Pumpanen, Ilvesniemi, \& Hari, 2003) believeed that the contribution of $\mathrm{CO}_{2}$ flux at bottom soils in winter to the total flux is greater than that in summer, while Risk (Risk, Kellman, \& Beltrami, 2008) proved that the contribution rate at deep soil was larger in the later growing season, all of which corroborated the results of our study to a certain extent, but there is also a certain heterogeneity. The reasons for this phenomenon may be that: thick soil layer was formed due to its unique soil development process in the loess hilly region, the hysteresis of the seasonal temperature change, the dry soil layer and temporary dry layer formed by water deficiency and provisional water deficiency have a great influence on the soil $\mathrm{CO}_{2}$ flux at the deep soil layer. The heterogeneity of the contribution in Robinia pseudoacacia of $\mathrm{CH10a}$ in the just confirms the fact that intensification of organic carbon mineralization induced by the rhizosphere stimuli in agricultural land and abandoned arable land (Shahzad et al., 2018).

\subsection{Analysis on factors affecting soil $\mathrm{CO}_{2}$ flux at different layers}

Climate-driven losses of soil carbon are currently occurring across many ecosystems, with a detectable and sustained trend emerging at the global scale (Bond-Lamberty, Bailey, Chen, Gough, \& Vargas, 2018). As the major driving factors of soil $\mathrm{CO}_{2}$ production, temperature and moisture vary vertically within the soil profile (Davidson E A, 2006), soil temperature rises slowly from the surface to the bottom in spring and begins to cool down from the surface (Subke et al., 2003). Soil organic carbon (SOC) is one of the key indexes for assessing soil quality. The content of soil organic carbon decreased with soil depth increasing and is significantly different at vertical profiles $(\mathrm{P}<0.01)$, and changes in SOC may have a huge potential impact on global climate. (Wang, Fu et al. 2010). Furthermore, related studies have shown that soil temperature and moisture explain the temporal and spatial variation of soil $\mathrm{CO}_{2}$ emissions. Similarly, changes in soil organic carbon significantly increase soil $\mathrm{CO}_{2}$ flux, and there was a strong positive correlation between $\mathrm{CO}_{2}$ flux and SOC (Mande et al., 2015).

Some scholars believe that the average $\mathrm{Q}_{10}$ of forests in the world is 1.5(Luo, Wan, Hui, \& Wallace, 2001), and the $\mathrm{Q}_{10}$ value of the forest in the north temperate zone was between 0.9 and 2.2 (Gulledge \& Schimel, 2000). In our study,the range of $\mathrm{Q}_{10}$ in Robinia pseudoacacia of different stand ages was $1.245 \pm 0.077$ to $2.121 \pm 0.404$, and $\mathrm{Q}_{10}$ value at different layers was significantly different $(\mathrm{P}<0.01)$. With the increase of soil depth, the $\mathrm{Q}_{10}$ at different layers increased, and the Q10 $(2.121 \pm 0.404)$ at deep layer $(200 \mathrm{~cm})$ was significantly higher than that $(1.245 \pm 0.077)$ at surface layer. A similar phenomenon observed in Georgia, USA, was that the $\mathrm{Q}_{10}$ increased with increasing the depth of the soil layer. and the researchers believed that this phenomenon may be caused by a decrease in soil temperature as the depth of the soil increases(Pingintha, Leclerc, Beasley, Zhang, \& Senthong, 2010), which may reflect root growth and root input at oligorganic layer has a relatively greater important effecct than that at O-horizon(Davidson, Savage, et al., 2006). And higher $\mathrm{Q}_{10}$ at deep layers may also be related to factors such as humidity limitation, nutrient availability and so on(Davidson, Janssens, \& Luo, 2006; Graf et al., 2008). Some other scholars have found that, in a deep warming experiment in mineral soil, all depths responded to warming with similar temperature sensitivities, driven by decomposition of decadal-aged carbon. Whole-soil warming revealed a larger soil respiration response than many in situ experiments and models (Pries, Castanha, Porras, \& Torn, 2017). Our study further confirmed that: under the external environment disturbance, the same temperature change occurs in deep layers as shallow layers, deep layers revealed a larger soil $\mathrm{CO}_{2}$ flux response than shallow layers. Therefore, the disturbance occurred at deep layers should be close concerned in future human activities and 
natural environment improvement.

The response mechanism of moisture to soil respiration is complicated, and the change of moisture in soil surface was generally larger than that in deep layers (Davidson E A, 2006). Therefore, soil $\mathrm{CO}_{2}$ flux at different layers will change due to fluctuations in moisture. In Kog.Ma experimental site of Thailand, Hashimoto et al. (Hashimoto et al., 2007) found that the $\mathrm{CO}_{2}$ flux at different layers varied with the change of moisture, and the $\mathrm{CO}_{2}$ flux of surface soil was larger in rainy seasons than that in dry seasons, while there presented the opposite trend at deep layers. Davidson et al. (Davidson E A, 2006)also found that the release rate of $\mathrm{CO}_{2}$ in the surface layer and O-layer of mineral soil was significantly correlated with moisture $(\mathrm{P}<0.001)$, but the correlation between the upper and middle layers of A-layer was vary low. This indicates that the effect of alternate drying-wetting on soil $\mathrm{CO}_{2}$ release only occurs at the O-layer. In our study, the changes of soil moisture inRobinia pseudoacacia of stand ages or at different layers were significant. There was certain quadratic function relation between soil $\mathrm{CO}_{2}$ flux and moisture(Fig6.), due to temperature and matrix and other factors at profile of $(20 \mathrm{~cm}-80 \mathrm{~cm})$ lying between surface layer and deep layer, the response of moisture to soil $\mathrm{CO}_{2}$ flux was relatively slow compared to the surface and deep layers. The reasons of above phenomenon may be that: destruction of soil aggregates accelerated by near-surface water replenishment leads to increase of matrix availability, and then which leads to enhance of microbial activity, all this stimulates $\mathrm{CO}_{2}$ emissions. At deep layes, soil $\mathrm{CO}_{2}$ flux, under the stimulation of water replenishment, the dominant mechanism affecting $\mathrm{CO}_{2}$ flux may shift from "substrate supply" to "microbial stress", and there presents a distinct feedback (J. Wang, Liu, Chen, Liu, \& Sainju, 2015).

In this study, soil $\mathrm{CO}_{2}$ flux increased with the increase of soil organic carbon at the lower layers. while it decreased at near-surface layers. Related studies suggested that soil organic carbon concentration decreased with increasing of soil depth in arid and semi-arid loess hilly area, and there was a significant difference in vertical profiles $(\mathrm{P}<0.01)$ (Y. F. Wang, Fu, Lu, Song, \& Luan, 2010). Based on the theory of Michaelis equation (Moorhead \& Weintraub, 2018), the concentration of organic carbon substrate used for mineralization reaction at the lower layer was not saturated, and it still had a positive feedback on mineralization rate. At the near-surface layers, in addition to the normal organic carbon sequestration process, the forest floor litter had a great influence on the physic-chemical environment, and the activities of microorganisms and roots were greatly changed. The feedback mechanism of organic carbon substrate on the $\mathrm{CO}_{2}$ flux became a far more complex, and thus soil organic carbon substrate showeds a certain negative feedback effect.

\section{4. synergistic effect and prediction models}

Mande believed that the soil temperature and moisture explained the spatial and temporal variation in soil $\mathrm{CO}_{2}$ flux. Likewise, the changes in the soil properties and forest carbon significantly increased the soil $\mathrm{CO}_{2}$ efflux indicating a strong positive correlation(Mande et al., 2015). In our study, multivariate correlation analysis was carried out on soil temperature, moisture, concentration of organic carbon and soil $\mathrm{CO}_{2}$ flux at different layers $(5-20 \mathrm{~cm}, 80-200 \mathrm{~cm})$. The results showed that there was a significant correlation $(\mathrm{P}<0.01)$ whether at the deep layer $(80-200 \mathrm{~cm})$ or shallow layers. All of above suggested that soil temperature, moisture, and soil organic carbon substrates all exhibited synergistic responses to soil $\mathrm{CO}_{2}$ flux whether at deep layers or shallow layers.

Chen et al. developed a T\&P\&C-model including SOC as an additional predictor of annual R-s. This extended but still simple model performed better than the T\&P-model and explained $69 \%$, $89 \%$, and $47 \%$ of the interannual and intersite variability of R-s for croplands, grasslands and forests, respectively. And the modeling efficiency of the T\&P\&C-model was nearly $60 \%$ across ecosystems. (Chen et al., 2010). In this study, based on the traditional hydrothermal two-factor models (T\&M models), combined with the environment and substrate characteristics of artificial Robinia pseudoacacia, a three-factor model of temperature $(\mathrm{T})$, moisture $(\mathrm{M})$ and organic carbon substrate $(\mathrm{C})$ was established at the deep and shallow layer, respectively(Table 4). Better estimates of $\mathrm{CO}_{2}$ flux at deep layers than shallow layers would be obtained with the new model driven by temperature $(\mathrm{T})$, moisture $(\mathrm{M})$ and organic carbon substrate together. In order to further verify the superiority of the T\&M\&C model, we selected vertical $\mathrm{CO}_{2}$ flux data of different ecosystems in different research areas through literature, and compared the accuracy of the T\&M\&C model 
with the T\&M model. The prediction accuracy (RMSE/MAE) was increased by average of $20 \sim 26 \%$, and T\&M\&C model was of better results in prediction effect. Therefore, the new multi-factor model driven by climate and soil properties can better estimate $\mathrm{CO}_{2}$ flux at different layers and should be widely used to predict global carbon emissions.

\subsection{Conclusion}

This study explored the process of deep soil carbon mineralization and diffusion to the soil-atmosphere interface, as well as the driving factors. We extended the study area of soil $\mathrm{CO}_{2}$ flux from shallow layer $(0-80$ $\mathrm{cm})$ to deep layer $(80-200 \mathrm{~cm})$, and soil $\mathrm{CO}_{2}$ fluxes were measured calculated at each profile. The results showed that the $\mathrm{CO}_{2}$ flux has a vertical decline and seasonal double-peak change trend; the contribute of $\mathrm{CO}_{2}$ flux at deep layers to the soil-atmosphere interface is stable, ranging from $21.81 \%$ to $24.42 \%$; The $\mathrm{CO}_{2}$ emissions at each profile were drived by soil temperature ,moisture, and soil organic carbon. It would cause more intense $\mathrm{CO}_{2}$ emissions in deep layers than the shallow layer after being stimulated by temperature disturbance. Soil moisture had strong influence on the $\mathrm{CO}_{2}$ flux at the near-surface and deep layers, but weaker at the layers of $20 \mathrm{~cm}$ and $80 \mathrm{~cm}$. The soil organic carbon had a certain reverse feedback effect on the $\mathrm{CO}_{2}$ flux at the near-surface and deep layers. To evaluate accuratly soil $\mathrm{CO}_{2}$ emissions and clarify the dynamic change mechanism of deep soil carbon pools, it was necessary to develop a new T \& M \& $\mathrm{C}$ prediction model based on the traditional two-factor empirical model of temperature and moisture, taking into account the role of soil organic carbon substrates.

\section{Acknowledgements}

This study was funded by the National Key Research and Development Program of China (No. 2017YFC0506503; No.2017YF0504600), National Natural Science Foundation of China (No.41771318), Scientific and Technologial Innovation Programs of Higher Education Institutions of Shanxi (No.2020L0680). We thank the Ansai Agro-Ecological Research Station on the Loess Plateau for providing experimental site and research support.

\section{References}

ArchMiller, A. A., Samuelson, L. J., \& Li, Y. R. (2016). Spatial variability of soil respiration in a 64-year-old longleaf pine forest.Plant and Soil, 403 (1-2), 419-435. doi:10.1007/s11104-016-2817-1

Ball, B. C., McTaggart, I. P., \& Watson, C. A. (2002). Influence of organic ley-arable management and afforestation in sandy loam to clay loam soils on fluxes of N2O and CH4 in Scotland. Agriculture Ecosystems \& Environment, 90 (3), 305-317. doi:Pii S0167-8809(01)00207-9

Doi 10.1016/S0167-8809(01)00207-9

Bond-Lamberty, B., Bailey, V. L., Chen, M., Gough, C. M., \& Vargas, R. (2018). Globally rising soil heterotrophic respiration over recent decades. Nature, 560 (7716), 80-83. doi:10.1038/s41586-018-0358-x

Certini, G., Corti, G., Agnelli, A., \& Sanesi, G. (2003). Carbon dioxide efflux and concentrations in two soils under temperate forests.Biology and Fertility of Soils, 37 (1), 39-46. doi:10.1007/s00374-002-0560-7

Chen, S. T., Huang, Y., Zou, J. W., Shen, Q. R., Hu, Z. H., Qin, Y. M., . . . Pan, G. X. (2010). Modeling interannual variability of global soil respiration from climate and soil properties. Agricultural and Forest Meteorology, 150 (4), 590-605. doi:10.1016/j.agrformet.2010.02.004

Davidson E A, S. K. E., Trumbore S E, Borken W. (2006). Vertical partitioning of $\mathrm{CO}_{2}$ production within a temperate forest soil. Global Change Biology, 12 (6), 944-956. doi:10.1111/j.1365-2486.2005.01142.x

Davidson, E. A., \& Ackerman, I. L. (1993). Changes in Soil Carbon Inventories Following Cultivation of Previously Untilled Soils.Biogeochemistry, 20 (3), 161-193. doi:Doi 10.1007/Bf00000786

Davidson, E. A., Janssens, I. A., \& Luo, Y. Q. (2006). On the variability of respiration in terrestrial ecosystems: moving beyond Q(10). Global Change Biology, 12 (2), 154-164. doi:10.1111/j.1365-2486.2005.01065.x 
Davidson, E. A., Savage, K. E., Trumbore, S. E., \& Borken, W. (2006). Vertical partitioning of CO2 production within a temperate forest soil.Global Change Biology, 12 (6), 944-956. doi:10.1111/j.13652486.2005.01142.x

Davidson, E. A., \& Trumbore, S. E. (1995). Gas Diffusivity and Production of $\mathrm{CO}_{2}$ in Deep Soils of the Eastern Amazon. Tellus Series B-Chemical and Physical Meteorology, 47 (5), 550-565. doi:DOI 10.1034/j.16000889.47.issue5.3.x

Davidson, E. A., Trumbore, S. E., \& Amundson, R. (2000). Biogeochemistry - Soil warming and organic carbon content. Nature, 408 (6814), 789-790. doi:Doi 10.1038/35048672

Fang C M, S. P., Moncrieff J B, Smith J U. (2005). Similar response of labile and resistant soil organic matter pools to changes in temperature. Nature, 433 (7021), 57-59. doi:10.1038/nature03138

Flechard, C. R., Ambus, P., Skiba, U., Rees, R. M., Hensen, A., van Amstel, A., . . . Grosz, B. (2007). Effects of climate and management intensity on nitrous oxide emissions in grassland systems across Europe.Agriculture Ecosystems \& Environment, 121 (1-2), 135-152. doi:10.1016/j.agee.2006.12.024

Fontaine, S., Barot, S., Barre, P., Bdioui, N., Mary, B., \& Rumpel, C. (2007). Stability of organic carbon in deep soil layers controlled by fresh carbon supply. Nature, 450 (7167), 277-U210. doi:10.1038/nature06275

Franzluebbers, A. J., Haney, R. L., Honeycutt, C. W., Arshad, M. A., Schomberg, H. H., \& Hons, F. M. (2001). Climatic influences on active fractions of soil organic matter. Soil Biology \&3 Biochemistry, 33 (7-8), 1103-1111. doi:Doi 10.1016/S0038-0717(01)00016-5

Friedlingstein, P., Dufresne, J. L., Cox, P. M., \& Rayner, P. (2003). How positive is the feedback between climate change and the carbon cycle? Tellus Series B-Chemical and Physical Meteorology, 55 (2), 692-700. doi:DOI 10.1034/j.1600-0889.2003.01461.x

Gaudinski, J. B., Trumbore, S. E., Davidson, E. A., \& Zheng, S. H. (2000). Soil carbon cycling in a temperate forest: radiocarbon-based estimates of residence times, sequestration rates and partitioning of fluxes. Biogeochemistry, 51 (1), 33-69. doi:Doi 10.1023/A:1006301010014

Graf, A., Weihermuller, L., Huisman, J. A., Herbst, M., Bauer, J., \& Vereecken, H. (2008). Measurement depth effects on the apparent temperature sensitivity of soil respiration in field studies.Biogeosciences, 5 (4), 1175-1188. doi:DOI 10.5194/bg-5-1175-2008

Gulledge, J., \& Schimel, J. P. (2000). Controls on soil carbon dioxide and methane fluxes in a variety of taiga forest stands in interior Alaska. Ecosystems, 3 (3), 269-282. doi:DOI 10.1007/s100210000025

Hanson, P. J., Edwards, N. T., Garten, C. T., \& Andrews, J. A. (2000). Separating root and soil microbial contributions to soil respiration: A review of methods and observations. Biogeochemistry, 48 (1), 115-146. doi:Doi 10.1023/A:1006244819642

Hashimoto, S., Tanaka, N., Kume, T., Yoshifuji, N., Hotta, N., Tanaka, K., \& Suzuki, M. (2007). Seasonality of vertically partitioned soil $\mathrm{CO}_{2}$ production in temperate and tropical forest. Journal of Forest Research, 12 (3), 209-221. doi:10.1007/s10310-007-0009-9

Hirano, T., Kim, H., \& Tanaka, Y. (2003). Long-term half-hourly measurement of soil CO2 concentration and soil respiration in a temperate deciduous forest. Journal of Geophysical Research-Atmospheres, 108 (D20), 4631. doi:Artn 4631

\subsection{9/2003jd003766}

Huang, S. D., Ye, G. F., Lin, J., Ruan, H. H., You, H. M., Xu, Z. Q., . . . Li, Q. X. (2018). The influence of drought on the soil CO2 flux at different depths in soil vertical profiles. Acta Ecologica Sinica, 38 (23), 8475-8488. doi:10.5846/stxb201711142028 
Jassal R, B. A., Novak M, Morgenstern K, Nesic Z, Gaumont-Guay D. (2005). Relationship between soil $\mathrm{CO}_{2}$ concentrations and forest-floor $\mathrm{CO}_{2}$ effluxes. Agricultural and Forest Meteorology, 130 (3-4), 176-192. doi:10.1016/j.agrformet.2005.03.005

Jobbagy, E. G., \& Jackson, R. B. (2000). The vertical distribution of soil organic carbon and its relation to climate and vegetation.Ecological Applications, 10 (2), 423-436.

Joos, O., Hagedorn, F., Heim, A., Gilgen, A. K., Schmidt, M. W. I., Siegwolf, R. T. W., \& Buchmann, N. (2010). Summer drought reduces total and litter-derived soil CO2 effluxes in temperate grassland - clues from a C-13 litter addition experiment. Biogeosciences, 7 (3), 1031-1041. doi:DOI 10.5194/bg-7-1031-2010

Kuzyakov, Y. (2006). Sources of CO2 efflux from soil and review of partitioning methods. Soil Biology $\mathscr{E}$ Biochemistry, 38 (3), 425-448. doi:10.1016/j.soilbio.2005.08.020

Lewicki, J. L., Evans, W. C., Hilley, G. E., Sorey, M. L., Rogie, J. D., \& Brantley, S. L. (2003). Shallow soil CO2 flow along the San Andreas and Calaveras Faults, California. Journal of Geophysical Research-Solid Earth, 108 (B4), 2187. doi:Artn 2187

$10.1029 / 2002 \mathrm{jb} 002141$

Liang N S, I. G., Fujinuma Y. (2003). A multichannel automated chamber system for continuous measurement of forest soil $\mathrm{CO}_{2}$ efflux. Tree Physiology, 23 (12), 825-832. doi:DOI 10.1093/treephys/23.12.825

Lou, Y. S., Li, Z. P., \& Zhang, T. L. (2003). Carbon dioxide flux in a subtropical agricultural soil of China. Water Air and Soil Pollution, 149 (1-4), 281-293. doi:Doi 10.1023/A:1025727504841

Luo, Y. Q., Wan, S. Q., Hui, D. F., \& Wallace, L. L. (2001). Acclimatization of soil respiration to warming in a tall grass prairie. Nature, 413 (6856), 622-625. doi:Doi 10.1038/35098065

Mande, H. K., Abdullah, A. M., Aris, A. Z., \& Ainuddin, A. N. (2015). Factors responsible for spatial and temporal variation of soil $\mathrm{CO}_{2}$ efflux in a 50 year recovering tropical forest, Peninsular Malaysia. Environmental Earth Sciences, 73 (9), 5559-5569. doi:10.1007/s12665-014-3810-8

Min, K., Berhe, A. A., Khoi, C. M., Asperen, H. V., \& Six, J. (2020). Differential effects of wetting and drying on soil CO2 concentration and flux in near-surface vs. deep soil layers. Biogeochemistry, a/n, a/n.

Moorhead, D. L., \& Weintraub, M. N. (2018). The evolution and application of the reverse Michaelis-Menten equation. Soil Biology \&3 Biochemistry, 125 , 261-262. doi:10.1016/j.soilbio.2018.07.021

Pang, X. Y., Bao, W. K., Zhu, B., \& Cheng, W. X. (2013). Responses of soil respiration and its temperature sensitivity to thinning in a pine plantation. Agricultural and Forest Meteorology, 171 , 57-64. doi:10.1016/j.agrformet.2012.12.001

Parsons, A. N., Barrett, J. E., Wall, D. H., \& Virginia, R. A. (2004). Soil carbon dioxide flux in Antarctic dry valley ecosystems.Ecosystems, 7 (3), 286-295. doi:10.1007/s10021-003-0132-1

Pingintha, N., Leclerc, M. Y., Beasley, J. P., Zhang, G. S., \& Senthong, C. (2010). Assessment of the soil $\mathrm{CO}_{2}$ gradient method for soil $\mathrm{CO}_{2}$ efflux measurements: comparison of six models in the calculation of the relative gas diffusion coefficient.Tellus Series B-Chemical and Physical Meteorology, 62 (1), 47-58. doi:10.1111/j.1600-0889.2009.00445.x

Post, W. M., \& Kwon, K. C. (2000). Soil carbon sequestration and land-use change: processes and potential. Global Change Biology, 6 (3), 317-327. doi:DOI 10.1046/j.1365-2486.2000.00308.x

Pries, C. E. H., Castanha, C., Porras, R. C., \& Torn, M. S. (2017). The whole-soil carbon flux in response to warming. Science, 355 (6332), 1420-1422. doi:10.1126/science.aal1319

Pumpanen, J., Ilvesniemi, H., \& Hari, P. (2003). A process-based model for predicting soil carbon dioxide efflux and concentration. Soil Science Society of America Journal, 67 (2), 402-413. 
Pumpanen, J., Ilvesniemi, H., Kulmala, L., Siivola, E., Laakso, H., Kolari, P., . . . Hari, P. (2008). Respiration in boreal forest soil as determined from carbon dioxide concentration profile. Soil Science Society of America Journal, 72 (5), 1187-1196. doi:10.2136/sssaj2007.0199

Richter, D. D., \& Mobley, M. L. (2009). Monitoring Earth's Critical Zone. Science, 326 (5956), 1067-1068.

Risk, D., Kellman, L., \& Beltrami, H. (2002). Soil CO2 production and surface flux at four climate observatories in eastern Canada. Global Biogeochemical Cycles, 16 (4), 1122-1134. doi:Artn 1122

10.1029/2001gb001831

Risk, D., Kellman, L., \& Beltrami, H. (2008). A new method for in situ soil gas diffusivity measurement and applications in the monitoring of subsurface $\mathrm{CO}(2)$ production. Journal of Geophysical ResearchBiogeosciences, 113 (G2), G02018. doi:Artn G02018

$10.1029 / 2007$ jg000445

Ryan, M. G., \& Law, B. E. (2005). Interpreting, measuring, and modeling soil respiration. Biogeochemistry, 73 (1), 3-27. doi:10.1007/s10533-004-5167-7

Schwendenmann, L., Veldkamp, E., Brenes, T., O’Brien, J. J., \& Mackensen, J. (2003). Spatial and temporal variation in soil $\mathrm{CO}_{2}$ efflux in an old-growth neotropical rain forest, La Selva, Costa Rica. Biogeochemistry, 64 (1), 111-128. doi:Doi 10.1023/A:1024941614919

Shahzad, T., Anwar, F., Hussain, S., Mahmood, F., Arif, M. S., Sahar, A., . . . Rashid, M. I. (2019). Carbon dynamics in surface and deep soil in response to increasing litter addition rates in an agro-ecosystem.Geoderma, 333 , 1-9. doi:10.1016/j.geoderma.2018.07.018

Shahzad, T., Rashid, M. I., Maire, V., Barot, S., Perveen, N., Alvarez, G., . . . Fontaine, S. (2018). Root penetration in deep soil layers stimulates mineralization of millennia-old organic carbon. Soil Biology $\mathcal{G}^{3}$ Biochemistry, 124 , 150-160. doi:10.1016/j.soilbio.2018.06.010

Springer, U., \& Klee, J. (2010). Prufung der Leistungsfhigkeit von einigen wichtigeren Verfahren zur Bestimmung des Kohlenstoffs mittels Chromschwefelsure sowie Vorschlag einer neuen Schnellmethode.Journal of Plant Nutrition Soil Science, 64 (1), 1-26.

Subke, J. A., Reichstein, M., \& Tenhunen, J. D. (2003). Explaining temporal variation in soil CO2 efflux in a mature spruce forest in Southern Germany. Soil Biology 83 Biochemistry, 35 (11), 1467-1483. doi:10.1016/S0038-0717(03)00241-4

Takahashi, A., Hiyama, T., Takahashi, H. A., \& Fukushima, Y. (2004). Analytical estimation of the vertical distribution of $\mathrm{CO}_{2}$ production within soil: application to a Japanese temperate forest. Agricultural and Forest Meteorology, 126 (3-4), 223-235. doi:10.1016/j.agrformet.2004.06.009

Tomotsune, M., Yoshitake, S., Iimura, Y., Kida, M., Fujitake, N., Koizumi, H., \& Ohtsuka, T. (2018). Effects of soil temperature and tidal condition on variation in carbon dioxide flux from soil sediment in a subtropical mangrove forest. Journal of Tropical Ecology, 34 , 268-275. doi:10.1017/S026646741800024x

Wang, C., Huang, Q., Yang, Z., Huang, R., \& Chen, G. (2011). Analysis of vertical profiles of soil CO_2 efflux in Chinese fir plantation.Acta Ecologica Sinica, 31 (19), 5711-5719. doi:10.1007/s11676-011-0141-4

Wang, J., Liu, Q. Q., Chen, R. R., Liu, W. Z., \& Sainju, U. M. (2015). Soil carbon dioxide emissions in response to precipitation frequency in the Loess Plateau, China. Applied Soil Ecology, 96 , 288-295. doi:10.1016/j.apsoil.2015.08.026

Wang, X., Fu, S., Li, J., Zou, X., Zhang, W., Xia, H., . . . Zhou, L. J. F. (2019). Forest Soil Profile Inversion and Mixing Change the Vertical Stratification of Soil CO2 Concentration without Altering Soil Surface CO2 Flux. 10 (2), 192-203. 
Wang, X., Liu, L. L., Piao, S. L., Janssens, I. A., Tang, J. W., Liu, W. X., . . . Xu, S. (2014). Soil respiration under climate warming: differential response of heterotrophic and autotrophic respiration. Global Change Biology, 20 (10), 3229-3237.

Wang, Y. F., Fu, B. J., Lu, Y. H., Song, C. J., \& Luan, Y. (2010). Local-scale spatial variability of soil organic carbon and its stock in the hilly area of the Loess Plateau, China. Quaternary Research, 73 (1), 70-76. doi:10.1016/j.yqres.2008.11.006

Wiaux F, V. M., Van Oost K. (2015). Vertical partitioning and controlling factors of gradient-based soil carbon dioxide fluxes in two contrasted soil profiles along a loamy hillslope. Biogeosciences, 12 (15), 46374649. doi:10.5194/bg-12-4637-2015

Willcock, S., Phillips, O. L., Platts, P. J., Swetnam, R. D., Balmford, A., Burgess, N. D., . . . Lewis, S. L. (2016). Land cover change and carbon emissions over 100 years in an African biodiversity hotspot.Glob Chang Biol, 22 (8), 2787-2800. doi:10.1111/gcb.13218

Woodwell, G. M., Whittaker, R. H., Reiners, W. A., Likens, G. E., Delwiche, C. C., \& Botkin, D. B. (1978). The biota and the world carbon budget. Science, 199 (4325), 141-146. doi:10.1126/science.199.4325.141

Zabowski, D., Whitney, N., Gurung, J., \& Hatten, J. (2011). Total Soil Carbon in the Coarse Fraction and at Depth. Forest Science, 57 (1), 11-18.

Zhang, Y. Y., Hu, X. Y., Zou, J., Zhang, D., Chen, W., Liu, Y., . . . Wang, X. Q. (2018). Response of surface albedo and soil carbon dioxide fluxes to biochar amendment in farmland. Journal of Soils and Sediments, 18 (4), 1590-1601. doi:10.1007/s11368-017-1889-8

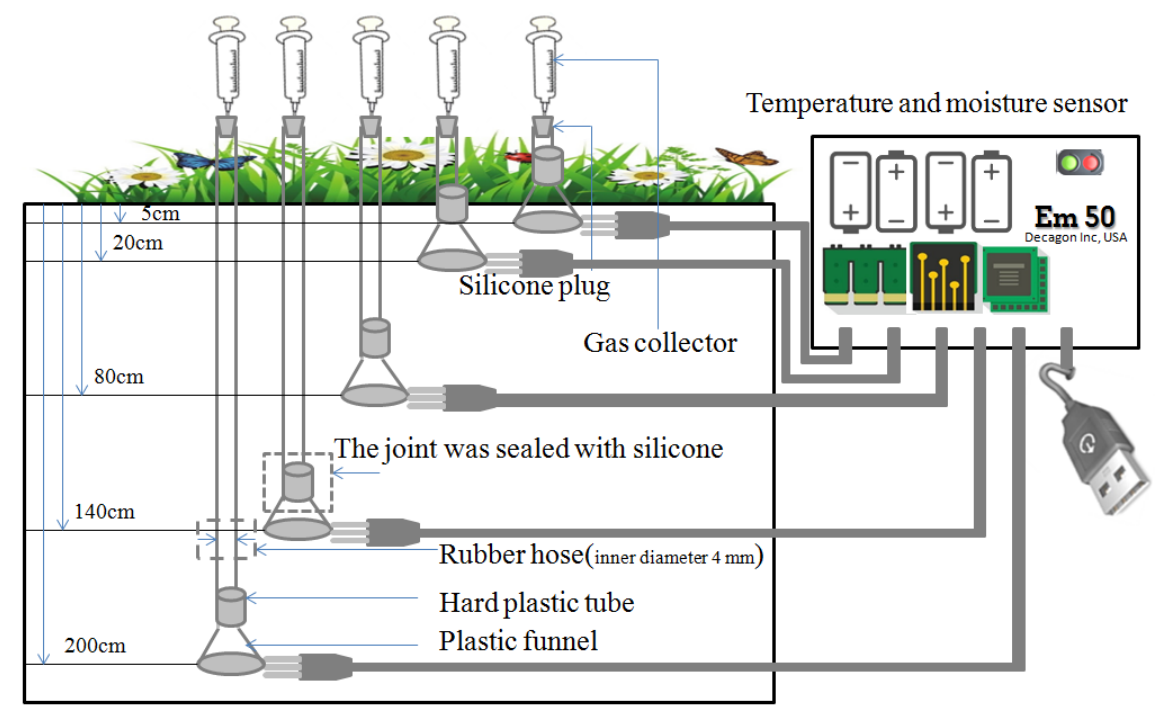

Fig.1 $\mathrm{CO}_{2}$ gas collection device and digital temperature and humidity sensor buried at different profiles for smapling.

Fig.2 Soil $\mathrm{CO}_{2}$ flux(A), temperature(B), and moisture(C) at different soil profiles in crop land and Robinia pseudoacacia of four kinds of stand age from sep.2012 to sep.2013.

\section{AB}

Fig.3 Contribution of $\mathrm{CO}_{2}$ flux at deep layers $(80-200 \mathrm{~cm})$ to the total $\mathrm{CO}_{2}$ flux of soil-atmosphere interface in different use-land types (crop land, CH10a, CH20a,CH30a,CH40a). Violin plot represents proportion of $\mathrm{CO}_{2}$ flux at deep profile $(80-200 \mathrm{~cm})$ to the total flux at soil-atmosphere interface in growing seasons and 
non-growing seasons (A ) . Box plot represents proportion of $\mathrm{CO}_{2}$ flux at deep profile $(80-200 \mathrm{~cm})$ to the total flux at soil-atmosphere interface in whole season $(\mathbf{B})$. Columnar plot represents the accumulated variance contribution of soil $\mathrm{CO}_{2}$ flux at deep profile $(80-200 \mathrm{~cm})$ to the total flux at soil-atmosphere interface in whole season of different land- use type (B).

Fig.4 The content of soil organic carbon $\left(\mathrm{g} \mathrm{kg}^{-1}\right)$ at different soil profiles depth $(0-5 \mathrm{~cm}, 5-20 \mathrm{~cm}, 20-80 \mathrm{~cm}, 80-$ $140 \mathrm{~cm}, 140-200 \mathrm{~cm})$ in crop land and Robinia pseudoacacia of four kinds of stand age $(\mathrm{CH} 10 \mathrm{a}, \mathrm{CH} 20 \mathrm{a}, \mathrm{CH} 30 \mathrm{a}$, $\mathrm{CH} 40 \mathrm{a})$. Values are means of three replicates $(\mathrm{n}=3)$ and error bars are standard errors of means. The letters in a column represent a significant difference $\left(\mathrm{p}_{i} 0.01\right)$ between means $(n=3)$ of different soil profiles depth within a land-use type.

Fig.5 Regression parameters and statistics equations for index model between soil $\mathrm{CO}_{2}$ flux $(\mathrm{F})$ and soil temperature $(\mathrm{T})$ in different profiles. The parameters (mean) are defined in Eqs. $\left(\mathrm{F}=\mathrm{a} \times \mathrm{e}^{\mathrm{bT}}\right) . \mathrm{Q}_{10}$, the proportional increase in soil $\mathrm{CO}_{2}$ flux with a 10 increase in temperature, $\mathrm{Q}_{10}=\mathrm{e}^{10 \mathrm{~b}}$, where, $\mathrm{b}$ is parameter in Eqs. $\left(\mathrm{F}=\mathrm{axe}^{\mathrm{bT}}\right) ; \mathrm{R}^{2}$, coefficient of determination; P-value, parameter testing regression significant.** Significant at the 0.01 probability level.

Fig.6 Regression parameters and statistics equations for quadratic Objective function model between soil $\mathrm{CO}_{2}$ flux $(\mathrm{F})$ and soil moisture $(\mathrm{M})$ in different profiles. The parameters (mean) are defined in Eqs. $\left(\left(\mathrm{F}=\mathrm{aM}^{2}+\mathrm{bM}+\mathrm{c}\right)\right) . \mathrm{R}^{2}$, coefficient of determination; P-value, parameter testing regression significant. * Significant at the 0.05 probability level, ${ }^{* *}$ Significant at the 0.01 probability level.

Fig.7 Correlation analysis between soil $\mathrm{CO}_{2}$ flux, temperature, moisture, and soil organic carbon in Shallow layer $(5-20 \mathrm{~cm})$ (Heat map: A ). Correlation analysis between soil $\mathrm{CO}_{2}$ flux, temperature, moisture, and soil organic carbon in layer $(80-200 \mathrm{~cm})$ (Heat map: B ). P-value, parameter testing correlation significant.

* Significant at the 0.05 probability level.

** Significant at the 0.01 probability level.

Fig.8 The $\mathrm{CO}_{2}$ flux at different soil temperature, moisture, and organic carbon . 3D-scatter diagram(a) presents the $\mathrm{CO}_{2}$ flux in shallow layers $(5-20 \mathrm{~cm})$. 3D-scatter diagram (b) presents the $\mathrm{CO}_{2}$ flux in deep layers $(80-200 \mathrm{~cm})$.

Fig.9 Observed and modeled $\mathrm{CO}_{2}$ flux in different ecosystems with the T\&M\&C-model. (a), (b) ,(c) , (d) , (e) and (f) represent temperate forests,subtropical forests,neotropical rain forests,mediterranean arable land,fir plantation,coniferous and broad-leaved forests, respectively; statistics are shown inAppendix A .

Fig.10 observed and modeled $\mathrm{CO}_{2}$ flux in different ecosystems with the T\&M-model. (a) , (b) ,(c) , (d) , (e) and (f) represent temperate forests,subtropical forests,neotropical rain forests,mediterranean arable land,fir plantation,coniferous and broad-leaved forests, respectively; statistics are shown inAppendix A .

Fig.11 Contribution rates of $T \& M \& C$ model to the $\mathrm{CO}_{2}$ flux estimation improvement compared with T\&M model.

Table 1 Description of sample plot used in the study.

\begin{tabular}{|c|c|c|c|c|c|}
\hline Sample plot & Altitude/m & Slope position & Slope/ ${ }^{\circ}$ & Aspect & $\begin{array}{l}\text { Mainly } \\
\text { vegetation } \\
\text { types of herb }\end{array}$ \\
\hline Siope land (crop) & 1307 & mid-slope & $15-20$ & east & Setaria italica \\
\hline $\begin{array}{l}\text { Robinia pseudoa- } \\
\text { cacia(10a) } \\
\text { (CH10a) }\end{array}$ & 1201 & mid & $21-24$ & west & $\begin{array}{l}\text { Artemisia } \\
\text { capillarie Thunb. } \\
\text { Lespedeza bicolor } \\
\text { Turcz. Stipa } \\
\text { bungeana Trin. }\end{array}$ \\
\hline
\end{tabular}




\begin{tabular}{|c|c|c|c|c|c|}
\hline Sample plot & Altitude/m & Slope position & Slope/ ${ }^{\circ}$ & Aspect & $\begin{array}{l}\text { Mainly } \\
\text { vegetation } \\
\text { types of herb }\end{array}$ \\
\hline $\begin{array}{l}\text { Robinia pseudoa- } \\
\text { cacia }(20 \mathrm{a}) \\
(\mathrm{CH} 20 \mathrm{a})\end{array}$ & 1103 & mid & $19-23$ & north by east & $\begin{array}{l}\text { Artemisia } \\
\text { giraldii Pamp. } \\
\text { Artemisia } \\
\text { scoparia } \\
\text { Waldst.et Kit. } \\
\text { Lespedeza bicolor } \\
\text { Turcz. }\end{array}$ \\
\hline $\begin{array}{l}\text { Robinia pseudoa- } \\
\text { cacia }(30 \mathrm{a}) \\
\text { (CH30a) }\end{array}$ & 1285 & mid & $23-25$ & north by east & $\begin{array}{l}\text { Artemisia } \\
\text { gmelinii Stipa } \\
\text { bungeana Trin. } \\
\text { Artemisia } \\
\text { giraldii Pamp. }\end{array}$ \\
\hline $\begin{array}{l}\text { Robinia pseudoa- } \\
\text { cacia }(40 \mathrm{a}) \\
(\mathrm{CH} 40 \mathrm{a})\end{array}$ & 1358 & mid & $22-24$ & East by South & $\begin{array}{l}\text { Artemisia } \\
\text { gmelinii } \\
\text { Artemisia } \\
\text { giraldii Pamp. } \\
\text { Artemisia } \\
\text { scoparia } \\
\text { Waldst.et Kit. }\end{array}$ \\
\hline
\end{tabular}

Table 2 Repeated measures ANOVA for effects of stand age and depth on monthly average of Soil $\mathrm{CO}_{2}$ flux, temperature and moisture.

\begin{tabular}{lllll}
\hline Term & $\mathrm{DF}$ & Soil $\mathrm{CO}_{2}$ flux(monthly mean) & Soil CO $_{2}$ flux(monthly mean) & Temperature (monthly mean \\
\hline & & F-Ratio & P Level & F-Ratio \\
land-use type & 4 & 1.320 & 0.262 & 0.940 \\
Depth & 4 & 256.550 & $i 0.001^{* *}$ & 0.030 \\
land-use type $\times$ Depth & 16 & 2.560 & $0.001^{* *}$ & 0.040 \\
Plot & 24 & & & \\
\hline
\end{tabular}

* Significant at the 0.05 probability level.

** Significant at the 0.01 probability level.

Table 3 Correlation analysis between soil $\mathrm{CO}_{2}$ flux (F) and the content of SOC at soil profile depth of $5 \mathrm{~cm}$, $20 \mathrm{~cm}, 80 \mathrm{~cm}, 140 \mathrm{~cm}, 200 \mathrm{~cm}$, and in crop land and Robinia pseudoacacia

\begin{tabular}{llllllll}
\hline & $\mathrm{SOC}^{\mathrm{a}}$ & $\mathrm{SOC}^{\mathrm{a}}$ & $\mathrm{SOC}^{\mathrm{a}}$ & $\mathrm{SOC}^{\mathrm{a}}$ & $\mathrm{SOC}^{\mathrm{a}}$ & $\mathrm{SOC}^{\mathrm{a}}$ & $\mathrm{SOC}^{\mathrm{a}}$ \\
\hline \multirow{3}{*}{ F Correlation coefficient } & $5 \mathrm{~cm}$ & $20 \mathrm{~cm}$ & $80 \mathrm{~cm}$ & $140 \mathrm{~cm}$ & $200 \mathrm{~cm}$ & Crop & Robinia pseudoacacia \\
& -0.233 & 0.258 & 0.172 & 0.249 & 0.332 & 0.710 & 0.680 \\
P-value & 0.064 & $0.037^{*}$ & 0.168 & $0.044^{*}$ & $0.007^{* *}$ & $\mathrm{¡}_{0.001^{* *}}$ & $\mathrm{j}_{0.001^{* *}}$ \\
\hline
\end{tabular}

* Significant at the 0.05 probability level.

** Significant at the 0.01 probability level. 
a SOC ,soil organic carbon .

Table 4 The prediction model of the $\mathrm{CO}_{2}$ flux about temperature (T), moisture (M) and SOC (C).

\begin{tabular}{|c|c|c|c|c|c|c|}
\hline Model & Depth & $\begin{array}{l}\text { Fitting } \\
\text { curve }\end{array}$ & $\mathrm{R}^{2}$ & RMSE & MAE & $\mathrm{P}$-value \\
\hline \multirow[t]{3}{*}{ Model I } & layer $(5-20 \mathrm{~cm})$ & & 0.144 & 0.882 & 0.707 & ¡0.001** \\
\hline & & \multicolumn{5}{|c|}{$F=0.226 \times e^{0.046 T} \times M^{-0.535}$} \\
\hline & $\begin{array}{l}\text { Deep layer }(80- \\
200 \mathrm{~cm}) \\
(\mathrm{n}=156)\end{array}$ & $F=0 .($ & $\begin{array}{l}0.460 \\
T \times M^{-}\end{array}$ & 0.098 & 0.073 & $¡ 0.001^{* *}$ \\
\hline \multirow[t]{3}{*}{ Model II } & $\begin{array}{l}\text { layer }(5-20 \mathrm{~cm}) \\
(\mathrm{n}=104)\end{array}$ & & 0.132 & 0.883 & 0.709 & $¡ 0.001^{* *}$ \\
\hline & & \multicolumn{5}{|c|}{$F=1.578^{\frac{T-10}{10}} \times\left(0.936-1.545 M+\frac{0.044}{M}\right)$} \\
\hline & $\begin{array}{l}\text { Deep layer }(80- \\
200 \mathrm{~cm}) \\
(\mathrm{n}=156)\end{array}$ & \multicolumn{5}{|c|}{$F=2.914^{\frac{T-10}{10}} \times\left(0.143-0.478 M+\frac{0.005}{M}\right)$} \\
\hline
\end{tabular}

$\mathrm{R}^{2}$, coefficient of determination. P-value, parameter testing regression significant.

* Significant at the 0.05 probability level. ** Significant at the 0.01 probability level.

Table 5 The prediction model of the $\mathrm{CO}_{2}$ flux about temperature $(\mathrm{T})$, moisture $(\mathrm{M})$ and SOC $(\mathrm{C})$.

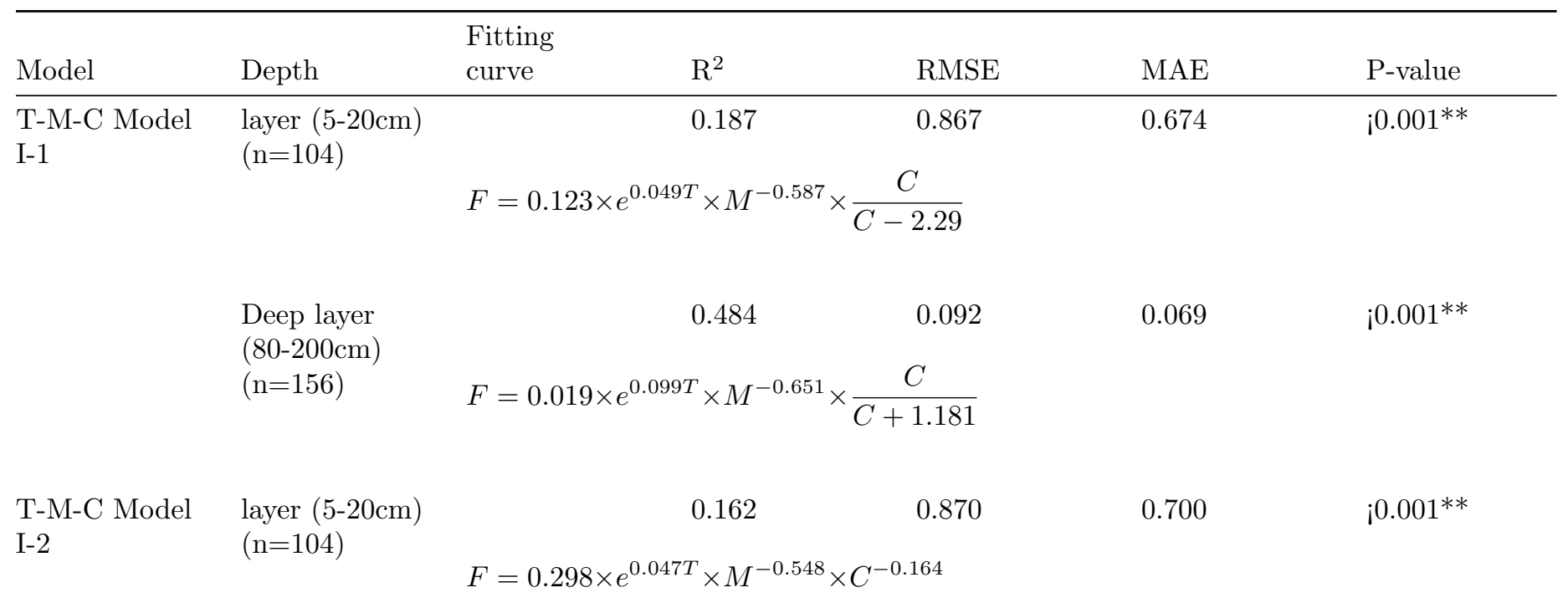




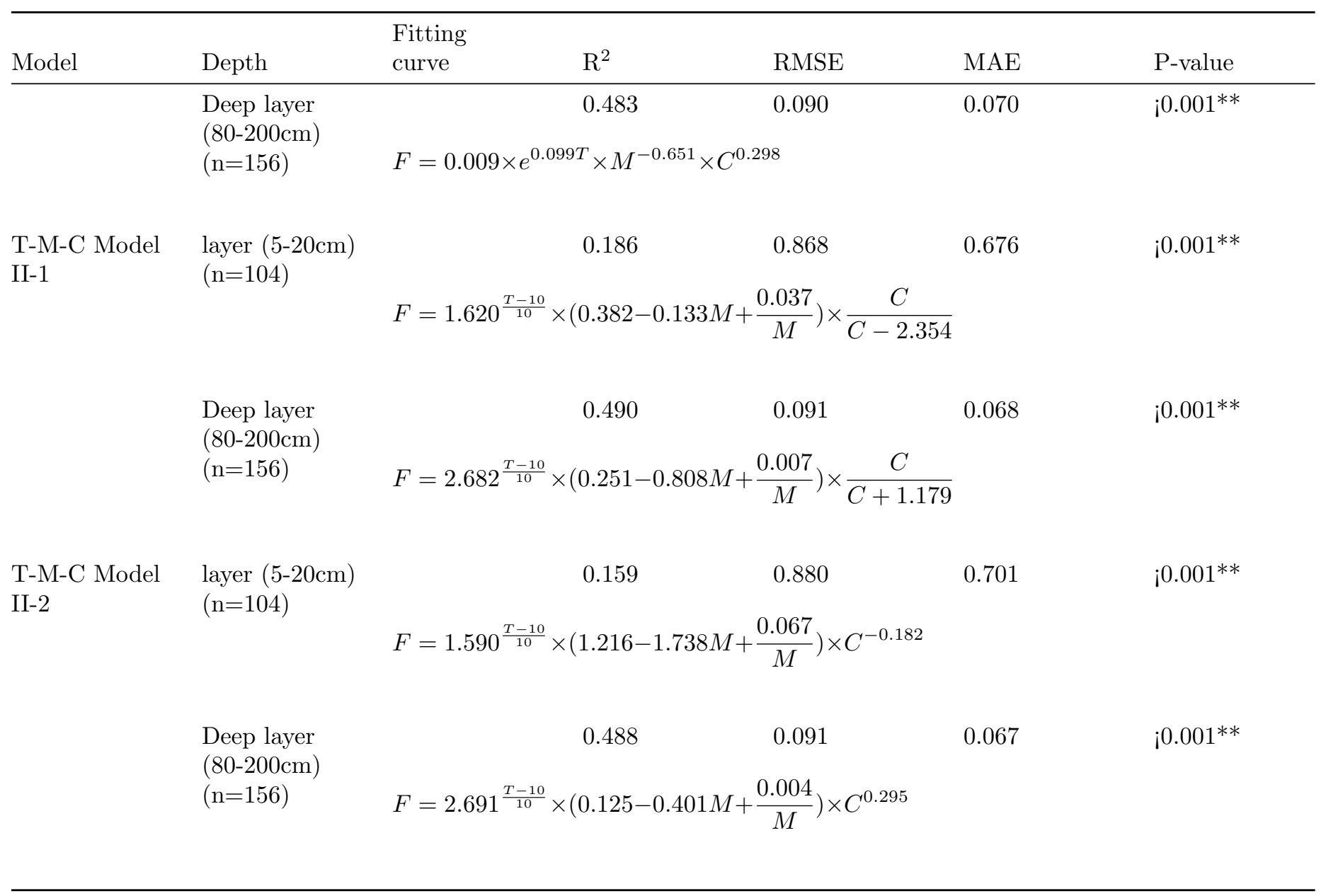

$\mathrm{R}^{2}$, coefficient of determination. P-value, parameter testing regression significant.

* Significant at the 0.05 probability level. ** Significant at the 0.01 probability level.

Appendix A Site characteristics, including soil $\mathrm{CO}_{2}$ flux $\left(\mathrm{F}, \mu \mathrm{mol} \mathrm{m} \mathrm{m}^{-2} \mathrm{~s}^{-1}\right)$, moisture $\left(\mathrm{M}, \mathrm{m}^{3} \mathrm{~m}^{-3}\right)$, temperature $\left(\mathrm{T}\right.$, ), soil organic carbon storage (SOC, $\left.\mathrm{g} \mathrm{kg}^{-1}\right)$.

\begin{tabular}{|c|c|c|c|c|c|c|c|c|}
\hline site & Latitude & Longitude & $\mathrm{n}$ & $\mathrm{F}$ & $\mathrm{T}$ & $\mathrm{M}$ & $\mathrm{SOC}$ & Refere \\
\hline $\begin{array}{l}\text { Florence, } \\
\text { Italy }\end{array}$ & $43^{\circ} 43^{\prime} \mathrm{N}$ & $11^{\circ} 33^{\prime} \mathrm{E}$ & 28 & $\begin{array}{l}0.09- \\
0.94\end{array}$ & $1.5-15.5$ & $\begin{array}{l}0.14- \\
0.46\end{array}$ & $\begin{array}{l}28.1- \\
40.8\end{array}$ & $\begin{array}{l}\text { (Certir } \\
\text { Corti, } \\
\text { Agnell } \\
\& \\
\text { Sanesi, } \\
2003 \text { ) }\end{array}$ \\
\hline $\begin{array}{l}\text { Guangdong, } \\
\text { China }\end{array}$ & $22^{\circ} 34^{\prime} \mathrm{N}$ & $\begin{array}{l}112^{\circ} 50^{\prime} \\
\mathrm{E}\end{array}$ & 120 & $\begin{array}{l}0.13- \\
2.46\end{array}$ & $6.3-40.7$ & $\begin{array}{l}0.26- \\
0.32\end{array}$ & $5.5-17.3$ & $\begin{array}{l}\text { (Xiaoli } \\
\text { Wang } \\
\text { al., } \\
2019 \text { ) }\end{array}$ \\
\hline
\end{tabular}




\begin{tabular}{|c|c|c|c|c|c|c|c|c|}
\hline site & Latitude & Longitude & $\bar{n}$ & $\mathrm{~F}$ & $\mathrm{~T}$ & $\mathrm{M}$ & $\mathrm{SOC}$ & Referen \\
\hline $\begin{array}{l}\text { La Selva, } \\
\text { Costa Rica }\end{array}$ & $10^{\circ} 20^{\prime} \mathrm{N}$ & $83^{\circ} 50^{\prime} \mathrm{W}$ & 100 & $0.39-1.29$ & $5.9-23.6$ & $0.28-0.66$ & $20.2-28.0$ & $\begin{array}{l}\text { Luitgar } \\
\text { (Schwe } \\
\text { denmar } \\
\text { Veldkar } \\
\text { Brenes, } \\
\text { O'Brier } \\
\text { Macken } \\
\text { 2003) }\end{array}$ \\
\hline Davis,USA & $32^{\circ} 10^{\prime} \mathrm{N}$ & $110^{\circ} 48^{\prime} \mathrm{W}$ & 92 & $\begin{array}{l}-0.57- \\
2.71\end{array}$ & $\begin{array}{l}15.2- \\
24.3\end{array}$ & $\begin{array}{l}0.08- \\
0.36\end{array}$ & $3.3-8.3$ & $\begin{array}{l}\text { (Min, } \\
\text { Berhe, } \\
\text { Khoi, } \\
\text { As- } \\
\text { peren, } \\
\text { \& Six, } \\
2020 \text { ) }\end{array}$ \\
\hline $\begin{array}{l}\text { Fujian, } \\
\text { China }\end{array}$ & $26^{\circ} 19^{\prime} \mathrm{N}$ & $117^{\circ} 36^{\prime} \mathrm{E}$ & 192 & $\begin{array}{l}0.05- \\
2.21\end{array}$ & $\begin{array}{l}10.4- \\
12.6\end{array}$ & $\begin{array}{l}0.10- \\
0.23\end{array}$ & $4.2-23.8$ & $\begin{array}{l}\text { (C. } \\
\text { Wang, } \\
\text { Huang, } \\
\text { Yang, } \\
\text { Huang, } \\
\text { \& Chen } \\
\text { 2011) }\end{array}$ \\
\hline $\begin{array}{l}\text { Wuyi } \\
\text { Moun- } \\
\text { tain, } \\
\text { China }\end{array}$ & $\begin{array}{l}27^{\circ} 33^{\prime}- \\
27^{\circ} 54^{\prime} \mathrm{N}\end{array}$ & $\begin{array}{l}117^{\circ} 27^{\prime}- \\
117^{\circ} 51^{\prime} \mathrm{E}\end{array}$ & 144 & $\begin{array}{l}0.08- \\
1.92\end{array}$ & $6.1-23.4$ & $\begin{array}{l}0.21- \\
0.38\end{array}$ & $\begin{array}{l}16.1- \\
82.5\end{array}$ & $\begin{array}{l}\text { (Huang } \\
\text { et al., } \\
2018 \text { ) }\end{array}$ \\
\hline
\end{tabular}

Appendix B Comparisons of $\mathrm{CO}_{2}$ flux estimation accuracy with different model based on the coefficient of determination $\left(\mathrm{R}^{2}\right)$, root mean square error (RMSE) and mean absolute error (MAE) for each ecosystem type.

\begin{tabular}{|c|c|c|c|c|c|c|c|c|}
\hline $\begin{array}{l}\text { Ecosystem } \\
\text { type }\end{array}$ & $\begin{array}{l}\text { Vertical } \\
\text { layers }\end{array}$ & $\begin{array}{l}\text { T-M } \\
\text { Model }\end{array}$ & $\mathrm{R}^{2}$ & RMSE & MAE & $\begin{array}{l}\text { T-M-C } \\
\text { Model }\end{array}$ & $\mathrm{R}^{2}$ & RMSE \\
\hline \multirow[t]{4}{*}{$\begin{array}{l}\text { Temperate } \\
\text { forests }\end{array}$} & $\begin{array}{l}\text { Shallow } \\
\text { layers }\end{array}$ & I & 0.49 & 0.33 & 0.29 & I-1 & 0.49 & 0.19 \\
\hline & & & & & & $\mathrm{I}-2$ & 0.51 & 0.21 \\
\hline & & II & 0.43 & 0.30 & 0.25 & II-1 & 0.56 & 0.19 \\
\hline & & & & & & II-2 & 0.49 & 0.21 \\
\hline \multirow[t]{4}{*}{$\begin{array}{l}\text { Subtropical } \\
\text { forests }\end{array}$} & $\begin{array}{l}\text { Shallow } \\
\text { layers }\end{array}$ & I & 0.49 & 0.39 & 0.32 & I-1 & 0.50 & 0.35 \\
\hline & & & & & & I-2 & 0.53 & 0.35 \\
\hline & & II & 0.41 & 0.38 & 0.31 & II-1 & 0.56 & 0.34 \\
\hline & & & & & & II-2 & 0.52 & 0.35 \\
\hline \multirow{4}{*}{$\begin{array}{l}\text { Neotropical } \\
\text { rain } \\
\text { forests }\end{array}$} & Shallow & I & 0.15 & 0.48 & 0.45 & $\mathrm{I}-1$ & 0.26 & 0.46 \\
\hline & & & & & & I- 2 & 0.10 & 0.43 \\
\hline & & II & 0.19 & 0.63 & 0.61 & II-1 & 0.19 & 0.35 \\
\hline & & & & & & II-2 & 0.15 & 0.57 \\
\hline
\end{tabular}




\begin{tabular}{|c|c|c|c|c|c|c|c|c|c|}
\hline $\begin{array}{l}\text { Ecosystem } \\
\text { type }\end{array}$ & $\begin{array}{l}\text { Vertical } \\
\text { layers }\end{array}$ & $\begin{array}{l}\text { T-M } \\
\text { Model }\end{array}$ & $\mathrm{R}^{2}$ & RMSE & MAE & $\begin{array}{l}\text { T-M-C } \\
\text { Model }\end{array}$ & $\mathrm{R}^{2}$ & RMSE & M \\
\hline \multirow{8}{*}{$\begin{array}{l}\text { Mediterranea } \\
\text { arable } \\
\text { land }\end{array}$} & $\begin{array}{l}\text { Whallow } \\
\text { layers }\end{array}$ & I & 0.40 & 0.82 & 0.69 & $\mathrm{I}-1$ & 0.33 & 0.80 & 0. \\
\hline & & & & & & $\mathrm{I}-2$ & 0.42 & 0.77 & 0. \\
\hline & & II & 0.46 & 0.82 & 0.71 & II-1 & 0.40 & 0.77 & 0. \\
\hline & & & & & & II-2 & 0.45 & 0.77 & 0. \\
\hline & $\begin{array}{l}\text { Deep } \\
\text { layers }\end{array}$ & I & 0.12 & 0.46 & 0.40 & $\mathrm{I}-1$ & 0.01 & 0.43 & 0. \\
\hline & & & & & & I-2 & 0.03 & 0.44 & 0 \\
\hline & & II & 0.12 & 0.40 & 0.35 & II-1 & 0.22 & 0.38 & 0. \\
\hline & & & & & & II-2 & 0.21 & 0.38 & 0. \\
\hline \multirow[t]{8}{*}{$\begin{array}{l}\text { Fir } \\
\text { plantation }\end{array}$} & $\begin{array}{l}\text { Shallow } \\
\text { layers }\end{array}$ & I & 0.92 & 0.74 & 0.69 & $\mathrm{I}-1$ & 0.81 & 0.34 & 0. \\
\hline & & & & & & $\mathrm{I}-2$ & 0.91 & 0.22 & 0 \\
\hline & & II & 0.92 & 0.73 & 0.69 & II-1 & 0.93 & 0.36 & 0. \\
\hline & & & & & & II-2 & 0.90 & 0.21 & 0. \\
\hline & $\begin{array}{l}\text { Deep } \\
\text { layers }\end{array}$ & I & 0.11 & 0.10 & 0.08 & $\mathrm{I}-1$ & 0.11 & 0.08 & 0. \\
\hline & & & & & & $\mathrm{I}-2$ & 0.11 & 0.08 & 0. \\
\hline & & II & 0.06 & 0.10 & 0.08 & II-1 & 0.11 & 0.05 & 0. \\
\hline & & & & & & II-2 & 0.11 & 0.10 & 0. \\
\hline \multirow{8}{*}{$\begin{array}{l}\text { Coniferous } \\
\text { and } \\
\text { broad- } \\
\text { leaved } \\
\text { forests }\end{array}$} & $\begin{array}{l}\text { Shallow } \\
\text { lavers }\end{array}$ & I & 0.18 & 0.38 & 0.30 & $\mathrm{I}-1$ & 0.42 & 0.35 & 0. \\
\hline & & & & & & $\mathrm{I}-2$ & 0.42 & 0.29 & 0. \\
\hline & & II & 0.07 & 0.36 & 0.27 & II-1 & 0.45 & 0.30 & 0. \\
\hline & & & & & & II-2 & 0.39 & 0.30 & 0. \\
\hline & $\begin{array}{l}\text { Deep } \\
\text { layers }\end{array}$ & I & 0.44 & 0.12 & 0.10 & I-1 & 0.44 & 0.08 & 0. \\
\hline & & & & & & $\mathrm{I}-2$ & 0.42 & 0.09 & 0. \\
\hline & & II & 0.24 & 0.20 & 0.19 & II-1 & 0.24 & 0.18 & 0. \\
\hline & & & & & & II-2 & 0.32 & 0.13 & 0. \\
\hline
\end{tabular}

